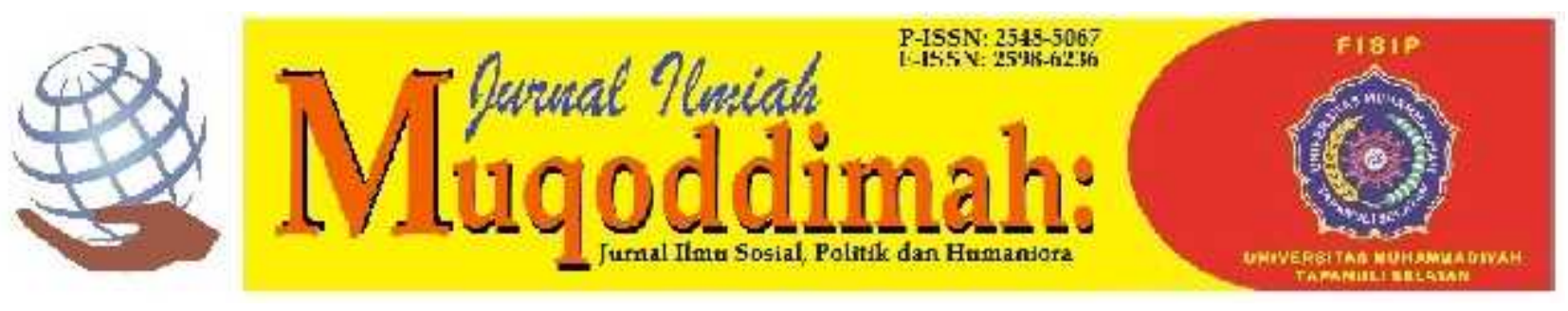

\title{
Analisis Pelaksanaan Program Desa Tangguh Bencana di Desa Buluh Cina, Siak Hulu, Kampar, Riau
}

\author{
Ainun Najib ${ }^{1}$, Hayatul Khairul Rahmat ${ }^{2)}$ \\ Universitas Pertahanan \\ Komplek Indonesia Peace and Security Center (IPSC) Sentul Bogor, Jawa Barat \\ ainun.najib@idu.ac.id ${ }^{1)}$ \\ hayatul.rahmat@idu.ac.id ${ }^{2)}$
}

\begin{abstract}
Abstrak
Desa Buluh Cina adalah salah satu desa di Kecamatan Siak Hulu, Kabupaten Kampar, Provinsi Riau yang menjadi Desa Tangguh Bencana. Daerah ini termasuk dalam peta bahaya banjir di Propinsi Riau. Tujuan dari penelitian ini adalah untuk menganalisis: (1) Partisipasi warga Desa Buluh Cina dalam mengelola sarana prasarana demi pengurangan risiko bencana banjir; (2) Peningkatan kemampuan penanggulangan bencana banjir oleh warga desa dan perangkat desa; dan (3) peran forum PRB Desa dalam penanggulangan bencana banjir. Metode yang digunakan dalam penelitian ini adalah kualitatif dengan metode wawancara. Hasil dari penelitian ini adalah; (1) Partisipasi warga Desa Buluh Cina sudah membuat bangunan yang tinggi untuk titik kumpul sementara ketika terjadi banjir guna pengurangan risiko bencana banjir, (2) Peningkatan kemampuan dalam penanggulangan bencana banjir, Desa Buluh Cina sebagai desa tangguh bencana aktif melakukan pelatihan rutin dan berkelanjutan sebagai usaha peningkatan kemampuan warga desa dan perangkat desa, dan (3) Peran forum PRB Desa Buluh Cina dalam penanggulangan bencana banjir dengan melakukan upaya mitigasi pasif dengan membuat jalur evakuasi ketika terjadi banjir. Selain itu, relawan PRB juga telah menyebar informasi melalui leaflet, brosur, dan pertemuanpertemuan desa lainnya sebagai upaya mitigasi dan peringatan dini bencana banjir.
\end{abstract}

Kata Kunci: Desa Tangguh Bencana, Bencana, Kesiapsiagaan

\begin{abstract}
Buluh Cina Village is one of the villages in Siak Hulu Subdistrict, Kampar Regency, Riau Province which is a Disaster Resilient Village. This area is included in the flood hazard map in Riau Province. The purpose of this study was to analyze: (1) The participation of the residents of Buluh Cina Village in managing infrastructure for reducing the risk of flood disasters; (2) Increasing the capacity of flood disaster management by villagers and village officials; and (3) the role of the Village PRB forum in flood disaster management. The method used in this research is qualitative with the interview method. The results of this study are; (1) The participation of the residents of Buluh Cina Village has made tall buildings for temporary gathering points when floods occur to reduce the risk of flood disasters, (2) Increasing capacity in flood disaster management, Buluh Cina Village as a disaster resilient village actively carries out routine and continuous training as a efforts to increase the capacity of villagers and village officials, and (3) The role of the Buluh Cina Village DRR forum in flood disaster management by undertaking passive mitigation efforts by creating an evacuation route when a flood occurs. Apart from that, DRR volunteers have also distributed information through leaflets, brochures and other village meetings as part of flood disaster mitigation and early warning.
\end{abstract}

Keywords: Resilient Village, Disaster, Disaster, Preparednes 


\section{PENDAHULUAN}

Kondisi geografis Indonesia sangat memungkinkan untuk terjadi bencana, baik yang disebabkan oleh faktor alam, faktor non alam maupun faktor manusia (Rahmat et al., 2018; Rahmat \& Alawiyah, 2020; Priambodo et al., 2020). Propinsi Riau yang dilalui empat sungai besar dan kondisi alam yang banyak memiliki rawa membuatnya sangat rawan dengan bencana banjir. Bencana banjir tersebut dapat menimbulkan korban jiwa, kerusakan lingkungan, kerugian harta benda, dan dampak psikologis (Rahmat et al., 2020). Maka diperlukan upaya pencegahan untuk penanggulangan bencana banjir dalam rangka meminimalkan risiko akibat banjir tersebut. Apalagi kebiasaan orang melayu Riau yang gemar mencari ikan dan membuat tempat tinggal di dekat sungai seperti desa Buluh Cina yang merupakan daerah aliran sungai Kampar, daerah itu termasuk dalam peta baha banjir di Propinsi Riau (BPBD, 2016).

BNPB sebagai kepanjangan tangan pemerintah telah membuat strategi melalui kebijakan agar pengurangan risiko bencana dilakukan berbasis masyarakat. Strategi tersebut adalah dengan membentuk Desa Tangguh Bencana yang dituangkan dalam bentuk Peraturan Kepala BNPB Nomor 1 Tahun 2012. Menurut Peraturan Kepala BNPB Nomor 1 Tahun 2012, Desa Tangguh Bencana adalah desa yang memiliki kemampuan mandiri untuk beradaptasi dan menghadapi ancaman bencana, serta memulihkan diri dengan segera dari dampak bencana yang merugikan, jika terkena bencana. Desa Tangguh Bencana adalah desa yang memiliki kemampuan mengenali potensi bencana, mengurangi potensi bencana dan mampu mengorganisasikan seluruh elemen masyarakat untuk berpartisipasi dalam penanggulangan bencana (Aini et al., 2018). Bentuk kapasitas Desa Tangguh Bencana terwujud melalui adanya perencanaan pembangunan yang mengandung upaya pencegahan dari potensi bencana, kesiapsiagaan serta pengurangan risiko bencana. Dalam Desa Tangguh Bencana, masyarakat berperan aktif dalam mengkaji, menganalisis, menangani, memantau, mengevaluasi dan mengurangi risiko bencana yang ada di wilayahnya, terutama memanfaatkan sumber daya lokal demi menjamin keberkelanjutan.

Tujuan dari pembentukan Desa Tangguh Bencana berdasarkan Peraturan Kepala BNPB Nomor 12 Tahun 2012 adalah:

1. Melindungi masyarakat di kawasan rawan bencana dari dampak bencana yang dapat menimbulkan kerugian.

2. Meningkatkan partisipasi masyarakat dalam pengelolaan sumber daya dan sarana prasarana untuk mengurangi risiko bencana.

3. Meningkatkan kapasitas kelembagaan masyarakat dalam pengelolaan sarana prasarana untuk PRB.

4. Meningkatkan kapasitas pemerintah dalam memberikan dukungan sumber daya dan teknis bagi PRB.

5. Meningkatkan kerjasama antara pihak yang berkepentingan dalam PRB, Pemerintah daerah, swasta, lembaga pendidikan tinggi, LSM, organisasi non pemerintah, dan kelompok peduli lainnya.

Program desa tangguh bencana memiliki enam komponen pokok, yaitu: 1) legislasi, 2) perencanaan, 3) kelembagaan, 4) pendanaan, 5) peningkatan kapasitas, dan 6) penyelenggaraan penanggulangan bencana (Muniar et al., 2017). Buluh Cina adalah salah satu desa di Kecamatan Siak Hulu, Kabupaten Kampar, Provinsi Riau 
yang menjadi Desa Tangguh Bencana. Buluh Cina secara geografis terletak pada koordinat $00^{\circ} 20^{\prime} 33^{\prime \prime} \mathrm{LU}-101^{\circ} 30^{\prime} 47^{\prime \prime} \mathrm{BT}$. Karena lokasinya yang berada di daerah aliran sungai Kampar dan merupakan dataran rendah sehingga memiliki potensi banjir sangat besar. Ini juga menjadi keunikan khusus desa tersebut sehingga dinobatkan menjadi salah satu desa wisata di Kabupaten Kampar (Hallo Riau, 2016).

Dari hasil pengamatan lapangan, bencana banjir sudah akrab dengan warga desa. Kondisi desa yang berada di bibir sungai dan konturnya yang berada di titik yang rendah seperti bekas endapan sungai yang terjadi ratusan tahun membuatnya sangat rawan banjir. Bahkan desa yang berada di bibir sungai kampar adalah wilayah daerah aliran sungai kampar (Pemerintah Kabupaten Kampar, 2018). Tanpa upaya mitigasi bencana, banjir akan menjadi ancaman dan dampak negatif yang cukup besar bagi kelangsungan kehidupan masyarakat daerah tersebut. Banjir yang terjadi akhir tahun 2019 merendam seluruh lokasi desa tersebut dan berlangsung lebih dari sepekan. Akibatnya seluruh aktivitas warga menjadi terganggu, baik pendidikan, pertanian, sampai pelayanan masyarakat di berbagai bidang (Kompas, 2019). Bencana banjir ini berulang setiap tahunnya pada saat musim penghujan tiba, apalagi apabila bendungan PLTA yang berada di hulu membuka pintu untuk mengurangi debit air..

Dengan demikian peningkatan kemampuan masyarakat melalui program desa tangguh bencana di Desa Buluh Cina merupakan program yang mendesak untuk dilaksanakan. Evaluasi terhadap peran forum PRB juga perlu ditingkatkan untuk lebih memaksimalkan kinerjanya dalam menghadapi bencana banjir. Maka penelitian ini bertujuan untuk: (1) menganalisis partisipasi warga Desa Buluh Cina dalam mengelola sarana prasarana demi pengurangan risiko bencana banjir; (2) menganalisis peningkatan kemampuan penanggulangan bencana banjir oleh warga desa dan perangkat desa; dan (3) menganalisis peran forum Pengurangan Risiko Bencana Desa dalam penanggulangan bencana banjir.

\section{METODE PENELITIAN}

Penelitian ini dilakukan di Desa Buluh Cina, Kecamatan Siak Hulu, Kabupaten Kampar, Propinsi Riau yang berada di daerah aliran sungai Kampar, dengan menggunakan metode penelitian kualitatif. Metode kualitatif bergantung pada teks dan data visual, metode ini memiliki analisis yang unik pada tahap analisis data, dan bertaruh pada desain yang beraneka ragam (Cresswell, 2014; Marufah et al., 2020). Data penelitian ini dikumpulkan dengan menggunakan metode wawancara dengan teknik semi terstruktur. Menurut Miles, Huberman, \& Saldana (2014) menyatakan bahwa aktivitas dalam analisis data kualitatif dilakukan secara interaktif dan berlangsung secara terus menerus sampai tuntas, sehingga datanya sudah jenuh.

Analisis data yang digunakan adalah analisis data deskriptif analitik yaitu dengan mendeskripsikan data yang dikumpulkan yang berasal dari naskah, wawancara, catatan lapangan, dokumen dan sebagainya kemudian dideskripsikan sehingga dapat memberikan kejelasan terhadap kenyataan atau realitas (Sudarto, 1997; Rahmat, 2019). Analisis data kualitatif tersebut dapat dilihat dalam gambar sebagai berikut: 


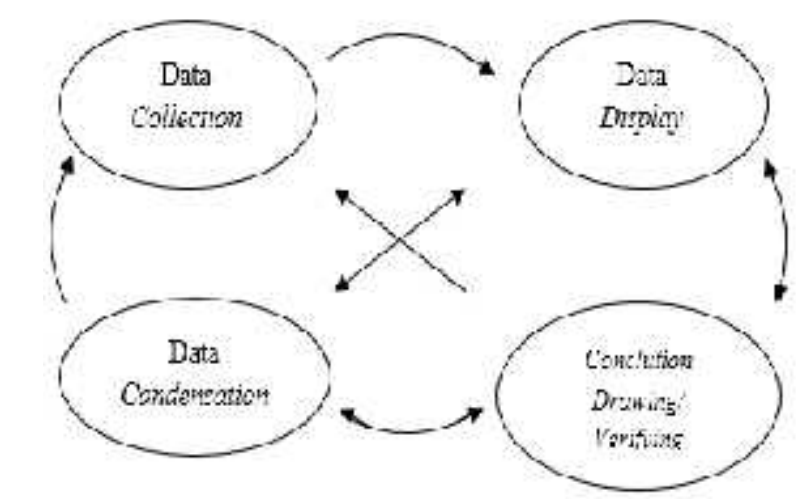

Gambar 1: Model Analisis Interaktif

Sumber: Miles, Huberman, \& Saldana (2014)

\section{HASIL DAN PEMBAHASAN}

Partisipasi Warga Desa Buluh China dalam Pengurangan Risiko Bencana Banjir

Menurut Sumaryadi (dalam Purnomo, 2010) menyebutkan bahwa partisipasi adalah peran serta seseorang atau sekelompok orang dalam proses pembangunan, baik dalam bentuk pernyataan maupun bentuk kegiatan dengan memberikan masukan pikiran, tenaga, waktu, keahlian, modal, materi, serta ikut memanfaatkan dan menikmati hasil-hasil pembangunan. Holil (dalam Labolo, 2010) mengemukakan unsur-unsur yang mempengaruhi partisipasi sebagai berikut:

1. Kepercayaan masyarakat.

2. Solidaritas dan integritas sosial masyarakat.

3. Tanggungjawab sosial dan komitmen masyarakat.

4. Kemauan dan kemampuan untuk mengubah atau memperbaiki keadaan dan membangun atas kekuatan sendiri.

5. Kepentingan umum murni, setidak-tidaknya umum dalam lingkungan yang bersangkutan.

6. Organisasi, keputusan rasional, dan efisiensi usaha.

7. Musyawarah untuk mufakat dalam pengambilan keputusan.

8. Prakarsa masyarakat atau perseorangan yang diterima dan diakui.

9. Kepekaan dan ketanggapan masyarakat terhadap masalah, kebutuhan, dan kepentingan umum masyarakat.

Dalam hal ini, untuk dapat melihat partisipasi masyarakat dalam pengurangan risiko bencana banjir di Desa Buluh Cina diawali dengan mengkaji legislasi. Desa Buluh Cina telah memiliki aturan terkait dengan bencana banjir yang setiap musim hujan melanda desa tersebut (BNPB, 2019). Perencanaan berupa aturan tersebut di bawah pembinaan dari BPBD Kabupaten Kampar sebagai pembina destana Kab. Kampar.

Aturan tersebut disusun bersama-sama dengan BPBD Kabupaten Kampar dalam rangka Pengurangan Risiko Bencana di Desa Buluh Cina. Aturan yang berbentuk Peraturan Desa Buluh Cina tersebut sudah disahkan dan disepakati bersama seluruh warga sejak tahun 2015. Di dalamnya berisi siapa berbuat apa, menentukan jalur evakuasi ketika terjadi banjir, menentukan titik kumpul sementara sampai pembuatan posko banjir di daerah aman terdekat. Ketika terjadi kesalahan standar operasional dalam pelaksanaan peraturan tersebut maka secepatnya dilakukan musyawarah desa untuk membahas kekurangan dari peraturan tersebut. 
Setelah ditetapkan legislasi, maka dilakukan perencanaan. Desa Buluh Cina sudah menyusun dokumen rencana penanggulangan bencana seperti rencana penanggulangan bencana, rencana aksi pengurangan risiko bencana atau rencana kontinjensi yang tersusun rapi bersamaan dengan pembentukan satuan tugas penanggulangan bencana. Dokumen-dokumen tersebut sudah dikonsultasikan dengan pihak BPBD Kabupaten Kampar sebagai pembina Destana, juga telah dipadukan ke dalam rencana pembangunan desa.

Dalam hal ini, dapat dilihat partisipasi warga Desa dihimpun dalam suatu Forum PRB. Forum PRB sudah ada di Desa Buluh Cina yang rutin mendapat pembinaan dari BPBD Kabupaten Kampar. Forum tersebut beranggotakan warga masyarakat yang terdiri dari tetua masyarakat, organisasi kepemudaan, dan organisasi perempuan dengan jumlah anggota aktif sekitar 40 orang. Forum PRB Desa Buluh Cina berpartisipasi aktif dengan program-program pengurangan risiko yang terencana dan dilaksanakan dengan baik sejak tahun 2010. Anggota forum PRB tersebut merupakan tim relawan/ siaga PB Desa yang terutama akan terlibat dalam tanggap darurat bencana, Pengurangan Risiko Bencana dan pendidikan kebencanaan.. Di samping sudah memiliki personil yang memadai, Desa Buluh Cina juga sudah memiliki peralatan yang memadai untuk melakukan pertolongan pada saat terjadi banjir.

Anggota relawan Desa Buluh Cina rutin melakukan kegiatan pelatihan, praktik simulasi, gelar SOP, dan gladi respons tanggap darurat bagi anggotanya bersama dengan masyarakat, melalui kegiatan-kegiatan yang terencana dan terprogram dengan baik. Dalam upaya pengurangan risiko bencana, Desa Buluh Cina sudah memiliki pembicaraan untuk menjalin kerjasama dengan desa tetangga seperti Desa Teratak Buluh, Desa Lubuk Siam, Desa Pangkalan Baru, dan desa-desa di sepanjang aliran sungai kampar. Kerjasama dengan pihak kecamatan, kabupaten, dan organisasi sosial. Terdapat perjanjian kerjasama yang disepakati bersama dengan organisasi sosial, sedangkan dengan kecamatan dan kabupaten dengan sistem birokrasi pada pemerintah daerah. Kegiatan-kegiatan pengurangan risiko bencana belum banyak dilaksanakan dengan melibatkan pihak swasta, dan lebih banyak dilakukan dengan pihak BPBD Kabupaten Kampar.

Dari uraian tersebut, dapat dilihat partisipasi warga Desa Buluh Cina dalam pengurangan risiko bencana banjir sesuai penelitian yang dilakukan oleh Pratiwi \& Meirinawati (2019). Dalam penelitian tersebut dikemukakan partisipasi masyarakat dapat dalam bentuk partisipasi buah pikiran, partisipasi harga benda, partisipasi keterampilan, dan partisipasi sosial (Hurerah, 2008; Noza, 2017).

\section{Peningkatan Kemampuan Penanggulangan Bencana Banjir oleh Warga Desa Buluh Cina}

Desa Buluh Cina telah mengalokasikan dana khusus yang akan digunakan untuk pengurangan risiko banjir yang dianggarkan dari dana desa melalui musyawarah desa. Demikian juga dana untuk tanggap darurat telah dianggarkan secara khusus mengingat setiap tahun terjadi banjir, sehingga alokasi dana tanggap darurat sudah dianggarkan dari dana desa. Upaya-upaya untuk mengalokasikan anggaran desa untuk kegiatankegiatan PRB juga sudah dilakukan, seperti pembuatan bangunan untuk titik kumpul sementara, pengadaan peralatan penanggulangan bencana dan pelatihan manajemen bencana. 
Kepala Desa Buluh Cina bersama dengan perangkatnya banyak melakukan upaya penanggulangan bencana, di antaranya melalui kegiatan pelatihan kebencanaan bagi aparat pemerintah desa, pelatihan terkait mekanisme pemeliharaan dan pemakaian perlengkapan, peralatan, sarana dan prasaranana, dan pelatihan pertolongan pertama ketika terjadi banjir. Pelatihan ini ditujukan tidak hanya kepada aparat desa tetapi juga kepada masyarakat dan relawan siaga bencana di desa. Tujuannya adalah untuk mengupayakan pengurangan risiko bencana, operasi tanggap darurat, dan pemulihan pasca bencana.

Pelatihan tentang dasar manajemen bencana, analisis risiko, kesiapsiagaan, dan operasi tanggap darurat rutin diberikan kepada aparat desa, relawan, dan warga masyarakat, terlebih memasuki musim-musim penghujan seperti bulan OktoberDesember. Pelatihan biasanya dilakukan dengan praktik evakuasi, operasi tanggap darurat, dan simulasi banjir. Juga penyebaran informasi kepada warga melalui pembagian leaflet terkait banjir dan cara penanggulangannya. Pelatihan ini rutin dilakukan setiap tahun yang melibatkan BPBD Kabupaten Kampar, Tim Reaksi Cepat (TRC), dan Basarnas Pekanbaru.

Relawan yang berpartisipasi aktif dalam satuan tugas penanggulangan bencana melalui kegiatan simulasi banjir, evakuasi korban banjir, dan operasi tanggap darurat terdiri dari seluruh warga masyarakat Buluh Cina, organisasi kepemudaan dan organisasi perempuan baik dari PKK, pengurus Posyandu, maupun pengurus dasa wisma. Masyarakat yang berpartisipasi aktif menjadi relawan ini sekitar 40 orang, ditambah dari organisasi perempuan yang berjumlah 15 orang, total yang aktif sekitar 55 orang.

Untuk peningkatan kemampuan dalam penanggulangan bencana banjir di Desa Buluh Cina, pemerintah desa sudah berupaya memberikan pelatihan-pelatihan kepada seluruh masyarakat yang terjun dalam tim relawan tangguh bencana di desa Buluh Cina, mulai dari aparat desa, tetua desa, karang taruna, dan kelompok perempuan. Tujuannya untuk upaya pengurangan risiko bencana, operasi tanggap darurat, dan pemulihan pasca bencana (Pradika, Giyarsih, \& Hartono, 2008; Rahmat et al., 2020). Peningkatan kapasitas ini rutin dilakukan setiap tahun terutama saat memasuki musim hujan, karena kawasan desa merupakan daerah yang rawan terhadap bencana banjir.

Pelatihan rutin dan keberlanjutan yang dilakukan menunjukkan adanya indikator keberhasilan desa dalam memiliki keterampilan dan pengetahuan, baik dari perencanaan, pelaksanaan, dan evaluasi dalam pengelolaan risiko bencana (SNI 8357, 2017). Adanya komunikasi antara tetua masyarakat, pemuda, forum penanggulangan bencana, dan seluruh relawan yang tergabung dalam satgas penanggulangan bencana serta fasilitator merupakan hal penting dalam peningkatan kapasitas (Kholimah, 2018). Selain itu, kepentingan lainnya adalah pengintegrasian kegiatan masyarakat, sehingga ketika di kemudian hari terjadi bencana banjir, semua itu menjadi kesepakatan dan tanggungjawab Bersama (Oktari, 2019).

Tim relawan di Desa Buluh Cina yang tergabung dalam tim satgas penanggulangan bencana terdiri atas seluruh komponen masyarakat, mulai dari aparat desa, karang taruna, dan kelompok perempuan yang terdiri dari PKK, Kelompok Dasawisma serta kader posyandu. Hal ini sejalan dengan prinsip destana yang merupakan gerakan kolektif dengan melibatkan dan mempertimbangkan seluruh pihak yang berkepentingan. 


\section{Peran Forum PRB Desa Buluh Cina dalam Pengurangan Risiko Bencana Banjir}

Peran dan partisipasi forum PRB Desa Buluh Cina terhadap bencana sudah bagus, hal ini dapat dilihat dari berbagai pihak yang tergabung dalam forum tersebut yang terdiri dari tetua masyarakat, karang taruna dan perempuan yang beroperasi sejak tahun 2010 dengan kekuatan personil aktif sebanyak 40 orang. Peran dan partisipasi warga masyarakat ini layak mendapat apresiasi karena sudah cukup lama masyarakat ikut berperan dalam penanggulangan banjir. Selain itu juga peran forum PRB ini didukung dengan peralatan yang cukup memadai untuk penanggulangan bencana banjir yang datang setiap musim penghujan.

Anggota forum Pengurangan Risiko Bencana Desa Buluh Cina cukup terlatih karena rutin melakukan pelatihan penanggulangan bencana yang terjadwal setiap tahun pada tingkat Kabupaten (BPBD Kabupaten Kampar) sejalan dengan maksud dan tujuan Peraturan Kepala BNPB No. 1 Tahun 2012 tentang Pedoman Umum Desa. Kegiatan Pengurangan Risiko Bencana pada tingkat desa belum banyak dilaksanakan karena masih mengacu pada kegiatan di tingkat Kabupaten (BPBD Kabupaten Kampar).

Upaya pemetaan dan analisis ancaman, penilaian kerentanan, dan peningkatan kapasitas warga masyarakat telah dilakukan sebagai upaya untuk pengurangan risiko bencana banjir. Jalur evakuasi dan tempat evakuasi sementara atau titik kumpul untuk tempat pengungsian ketika terjadi banjir sudah ada dan sudah dilengkapi dengan sarana darurat seperti P3K, obat-obat dan, dan penerangan darurat. Untuk kemudian korban banjir akan dievakuasi di posko yang biasanya di kantor camat, karena kebetulan lokasi terdekat dengan desa Buluh Cina adalah kantor camat.

Sebagai upaya peringatan dini kepada masyarakat, telah dilakukan penyebaran informasi melalui pertemuan-pertemuan, misalnya pada kegiatan arisan rutin di setiap RT, maupun dalam bentuk leaflet. Upaya ini terbukti efektif dilakukan di desa Buluh Cina meskipun dengan cara yang masih sederhana, karena pada saat penyebaran informasi tersebut telah diberikan pemahaman siapa yang melakukan apa, bagaimana melakukan pertolongan kepada kelompok rentan, juga bagaimana kesiapsiagaan menghadapi banjir tersebut dengan simulasi banjir, melakukan evakuasi korban, dan penyelematan diri.

Perlindungan kepada kelompok rentan seperti ibu hamil, orang tua, orang berkebutuhan khusus, dan anak-anak dilakukan dengan metode dan teknik yang dijalankan oleh seluruh perangkat desa termasuk Ketua RT dan Ketua RW bersama dengan tenaga kesehatan desa seperti bidan, dibantu dengan tenaga kesehatan dari kecamatan. Upaya perlindungan terhadap aset-aset desa juga dilakukan oleh aparat desa. Sedangkan untuk hewan ternak dilakukan secara bergotong royong sesama warga masyarakat. Tetapi belum dilakukan dengan pengelolaan dan mekanisme yang jelas dan terukur.

Berdasarkan uraian di atas, dipahami bahwa forum pengurangan risiko bencana Desa Buluh Cina berperan dimulai dari tahap kesiapsiagaan bencana. Sama halnya dengan Handriyana \& Cholid (2017) yang menjelaskan bahwa Forum PRB sangat penting berperan guna mengurangi risiko bencana dengan meningkatkan kesiapsiagaan menghadapi bencana tersebut. 


\section{SIMPULAN}

Berdasarkan hasil penelitian yang telah diuraikan di atas, maka didapatkan kesimpulan sebagai berikut:

1. Partisipasi warga Desa Buluh Cina dalam pengurangan risiko bencana banjir dilakukan melalui forum PRB Desa Buluh Cina telah dibentuk sejak tahun 2010 yang terdiri dari tetua masyarakat, organisasi kepemudaan, dan organisasi perempuan, yang artinya sudah satu dekade forum PRB tersebut aktif. Forum PRB di Desa Buluh Cina sudah terlatih karena sudah rutin melakukan pelatihan penanggulangan bencana yang terjadwal setiap tahun pada tingkat kabupaten. Kemudian dalam upaya mitigasi, personil dari forum penanggulangan bencana membuat titik kumpul sementara dan perlengkapan pertolongan pertama ketika terjadi bencana banjir.

2. Guna meningkatkan kemampuan dalam pengurangan risiko bencana banjir, Desa Buluh Cina telah aktif melakukan pelatihan rutin dan berkelanjutan setiap tahun sebagai usaha peningkatan kemampuan masyarakat dalam pengurangan risiko bencana banjir. Dari pelatihan tersebut terdapat indikator keberhasilan program desa tangguh bencana dengan memiliki keterampilan dan pengetahuan baik dari perencanaan, pelaksanaan, maupun evaluasi dalam upaya pengurangan risiko bencana.

3. Adapun beberapa peran dari Forum PRB di Desa Buluh Cina yaitu melakukan upaya mitigasi pasif, misalnya membuat pemetaan dan analisis risiko bencana dan sudah disahkan dan disepakati bersama sebagai peraturan desa. Anggota forum PRB telah melakukan upaya peringatan dini dengan penyebaran informasi melalui pertemuanpertemuan di tingkat RT maupun penyebarab leaflet dan brosur. Selain itu, tim PRB juga sudah membuat aula untuk tempat berkumpul sementara, pemasangan tanda bahaya, dan menyediakan tempat-tempat pengungsian darurat jika terjadi bencana dengan memanfaatkan fasilitas desa sebagai upaya mitigasi aktif. Selain itu juga melakukan kerjasama dengan beberapa desa tetangga untuk upaya penanggulangan bencana banjir yang datang setiap musim hujan.

Adapun rekomendasi dari penelitian ini adalah perlu melibatkan masyarakat lebih aktif lagi dalam pengurangan risiko bencana banjir dan juga perlu pengurangan risiko bencana banjir yang berkelanjutan di masa depan.

\section{DAFTAR PUSTAKA}

Aini, N., Ulfah, I. F., \& Afala, L. M. (2018). Efektivitas Program Desa Tangguh Bencana di Desa Sirnoboyo Kecamatan Pacitan Kabupaten Pacitan Tahun 2017. Journal of Governance and Policy, 4(2), 50-61.

BNPB. (2019). Peta Ancaman Bencana Kabupaten Kampar

BPBD Provinsi Riau. (2016). Peta Bahaya Banjir Di Propinsi Riau Tahun 2016.

Buchari, A., Santoso, M. B., Marlina, N. (2017). Pengembangan Kapasitas Kelembagaan Desa Tangguh Bencana di Kabupaten Garut (Studi di Desa Pasawahan Kecamatan Tarogong Kaler). JAKPP: Jurnal Analisis Kebijakan dan Pelayanan Publik, 3(1), 49-62.

Creswell, J. (2014). Research Design: Qualitative, Quantitative, and Mixed Methods Approaches. United Kingdom: SAGE.

Dinas Perhubungan Pariwisata dan Infokom Kabupaten Kampar. (2016). Daerah Objek Tujuan Wisata Di Kabupaten Kampar Tahun 2008. 
Hallo Riau. (2019). Aneh Lokasi Banjir Di Kampar Malah Jadi Tempat Wisata-Dadakan. Retrieved from https://www.halloriau.com/read-otonomi-123475-2019-12-24-anehlokasi-banjir-di-kampar-malah-jadi-tempat-wisata-dadakan.html, diakses tanggal 7 April 2020.

Handriyana, \& Cholid, S. (2017). Peran Forum Pengurangan Risiko Bencana Desa Pasawahan Kabupaten Garut dalam Kesiapsiagaan Bencana. Jurnal IImu Kesejahteraan Sosial, 18(1), 48-58.

Hurareh, A. (2008). Perorganisasian, Pengembangan Masyarakat Model dan Strategi Pembangunan Berbasis Masyarakat. Bandung: Humaniora.

Kholimah, D. D. (2018). Implementasi Kebijakan Desa Tangguh Bencana Oleh Badan Penanggulangan Bencana Daerah Kabupaten Klaten. E-Civics: Jurnal Pendidikan Kewarganegaraan dan Hukum, 7(7),

Kompas. (2019). Banjir Di Desa Buluh Cina Kampar Masih Tinggi Rendam Ratusan Rumah. Retrieved from https://regional.kompas.com/read/2019/12/19/20193011/banjir-di-desa-buluh-cinakampar-masih-tinggi-rendam-ratusan-rumah?page=all, diakses tanggal 7 April 2020.

Labolo, M. (2010). Memahami Ilmu Pemerintahan. Jakarta: Rajawali Press.

Marufah, N., Rahmat, H. K., \& Widana, I. D. K. K. (2020). Degradasi Moral sebagai Dampak Kejahatan Siber pada Generasi Millenial di Indonesia. NUSANTARA: Jurnal IImu Pengetahuan Sosial, 7(1), 191-120.

Miles, M. B., Huberman, A. M., \& Saldana, J. (2014). Qualitative Data Analysis: A Method Sourcebook. Jakarta: UI Press.

Munir, M., Harsasto, P., \& Taufiq, A. (2017). Evaluasi Pelaksanaan Program Desa Tangguh Bencana di Kabupaten Kendal Tahun 2016. Journal of Politic and Government Studies, 6(3), 421-430.

Noza, N. (20170. Partisipasi Masyarakat dalam Program Desa Tangguh Bencana di Desa Teluk Bakau Kabupaten Bintan. Jurnal Online Mahasiswa Fakultas IImu Sosial dan Ilmu Politik, 6(5), 1-15.

Oktari, R. S. (2019). Peningkatan Kapasitas Desa Tangguh Bencana. Jurnal Pengabdian Kepada Masyarakat, 4(2), 189-197.

Pemerintah Kabupaten Kampar. (2018). Profll Kabupaten Kampar. Retrieved from https://kominfosandi.kamparkab.go.id/peta-wilayah/, diakses tanggal 20 April 2020.

Peraturan Kepala Badan Nasional Penanggulangan Bencana No. 4 Tahun 2008 Tentang Pedoman Penyusunan Rencana Penanggulangan Bencana.

Peraturan Kepala Badan Nasional Penanggulangan Bencana Nomor 1 Tahun 2012 Tentang Pedoman Umum Desa/ Kelurahan Tangguh Bencana.

Pradika, M. I., Giyarsih, S. R., \& Hartono. (2018). Peran Pemuda dalam Pengurangan Risiko Bencana dan Implikasinya Terhadap Ketahanan Wilayah Desa Kepuharjo Kecamatan Cangkringan Kabupaten Sleman Daerah Istimewa Yogyakarta. Jurnal Ketahanan Nasional, 24(2), 261-286.

Pratiwi, D. I., \& Meirinawati. (2019). Partisipasi Masyarakat dalam Program Desa Tangguh Bencana (Destana) di Desa Pilangsari Kabupaten Bojonegoro. Publika, 7(7), 1-7.

Priambodo, A., Widyaningrum, N., \& Rahmat, H. K. (2020). Strategi Komando Resor Militer 043/ Garuda Hitam dalam Penanggulangan Bencana Alam di Provinsi Lampung. PERSPEKTIF, 9(2), 307-313. 
Purnomo, H. (2010). Manajemen Bencana, Respon dan Tindakan Terhadap Bencana. Yogyakarta: Media Pressindo.

Rahmat, H. K. (2019). Mobile Learning Berbasis Appypie sebagai Inovasi Media Pendidikan untuk Digital Natives dalam Perspektif Islam. Tarbawi: Jurnal Pendidikan Islam, 16(1).

Rahmat, H. K., \& Alawiyah, D. (2020). Konseling Traumatik: Sebuah Strategi Guna Mereduksi Dampak Psikologis Korban Bencana Alam. Jurnal Mimbar: Media Intelektual Muslim dan Bimbingan Rohani, 6(1), 34-44.

Rahmat, H. K., Banjarnahor, J., Ma'rufah, N., \& Widana, I. D. K. K. (2020). Pemberdayaan Masyarakat oleh Bintara Pembina Desa (Babinsa) dalam Meningkatkan Kesejahteraan Rakyat. NUSANTARA: Jurnal IImu Pengetahuan Sosial, 7(1), 91-107.

Rahmat, H. K., Kasmi, \& Kurniadi, A. (2020). Integrasi dan Interkoneksi antara Pendidikan dan Nilai-Nilai Qur'ani dalam Upaya Pengurangan Risiko Bencana di Sekolah Menengah Pertama. Prosiding Konferensi Integrasi Interkoneksi Islam dan Sains, 2, 455-461.

Rahmat, H. K., Nurmalasari, E., \& Basri, A. S. H. (2018). Implementasi Konseling Krisis Terintegrasi Sufi Healing Untuk Menangani Trauma Anak Usia Dini pada Situasi Krisis Pasca Bencana. Prosiding Seminar Nasional PIT ke- 5 Riset Kebencanaan IABI, 671-678.

Sari, D. R. (2020). Manajemen Risiko Bencana dalam Desa Tangguh Bencana di Badan Penanggulangan Bencan Daerah Kabupaten Purworejo. Journal of Public Policy and Management Review, 9(1), 1-16.

SNI 8357. (2017). Desa/ Kelurahan Tangguh Bencana. Badan Standarisasi Nasional. Sudarto. (1997). Metodologi Penelitian Filsafat. Jakarta: Raja Grafindo Persada. Undang-Undang Nomor 24 Tahun 2007 Tentang Penanggulangan Bencana. 